\title{
Understanding circular economy in everyday life : Perceptions of young adults in the Finnish context
}

\section{Korsunova-Tsaruk, Angelina}

2021-04

Korsunova-Tsaruk, A , Horn , S \& Vainio , A 2021, ' Understanding circular economy in everyday life : Perceptions of young adults in the Finnish context ' , Sustainable Production and Consumption , vol. 26 , pp. 759-769 . https://doi.org/10.1016/j.spc.2020.12.038

http://hdl.handle.net/10138/328762

https://doi.org/10.1016/j.spc.2020.12.038

CC BY

publishedVersion

Downloaded from Helda, University of Helsinki institutional repository.

This is an electronic reprint of the original article.

This reprint may differ from the original in pagination and typographic detail.

Please cite the original version. 
Research article

\title{
Understanding circular economy in everyday life: Perceptions of young adults in the Finnish context
}

\author{
Angelina Korsunova ${ }^{\mathrm{a}, *}$, Susanna Horn ${ }^{\mathrm{b}}$, Annukka Vainio ${ }^{\mathrm{a}}$ \\ ${ }^{a}$ Faculty of Agriculture and Forestry, Helsinki Institute of Sustainability Science, University of Helsinki, P.O. Box 4, Yliopistonkatu 3, 00014, Finland \\ ${ }^{\mathrm{b}}$ Center for Sustainable Consumption and Production at the Finnish Environment Institute (SYKE), Latokartanonkaari 11, FI-00790, Helsinki, Finland
}

\section{A R T I C L E I N F O}

\section{Article history:}

Received 1 October 2020

Revised 23 December 2020

Accepted 26 December 2020

Available online 28 December 2020

Editor: Prof Ioannis Nikolaou

\section{Keywords:}

Circular economy

Citizen roles

Youth

Well-being

Sustainability education

\begin{abstract}
A B S T R A C T
It is generally accepted that governments, municipalities, businesses and citizens alike have a role to play in transitioning towards a circular economy (CE). Yet most academic and policy discussions of CE revolve around technological solutions and business models. Although $\mathrm{CE}$ also means significant changes to ways of living, these aspects of CE are barely addressed. The citizen role is traditionally assumed to be that of a consumer or user of the newly developed solutions, while also following the guidelines for sorting and recycling. Little is known about how citizens envision being part of the $C E$, and what skills and competences are relevant for CE. Our study addresses this gap by exploring the perceptions of young adults in Finland on how CE reflects into their everyday lives. Our dataset consists of 249 responses from high school students in Finland to open-ended questions regarding CE. The results highlight that young adults in Finland strongly associate CE with recycling, waste sorting and re-selling/buying second-hand, which is in line with the conventional roles of efficient recyclers and consumers. Although CE harbors wider potential for more active citizen roles related to repair, maintenance and upcycling, these aspects are often overlooked in favor of more familiar lifestyles. Building on the 5R framework for CE and emerging themes from student responses, we bring forward the new roles of upcycler, thrifter, expert/learner, giver/benefactor and conservationist. Supporting these emerging roles is an opportunity for cooperation between young adults, other citizen groups, cities, policy makers and businesses, and a key for jointly advancing the transition to $\mathrm{CE}$.
\end{abstract}

(c) 2021 The Authors. Published by Elsevier B.V. on behalf of Institution of Chemical Engineers. This is an open access article under the CC BY license (http://creativecommons.org/licenses/by/4.0/)

\section{Introduction}

It is generally accepted that governments, municipalities, businesses and citizens alike have a role to play in transitioning towards a circular economy (CE). The European Commission (EC) has set ambitious targets for CE and climate neutrality by 2050 (EC, 2019; EC, 2020). To fulfil this ambition, it is acknowledged that the different societal actors need "to accelerate the transition towards a regenerative growth model that gives back to the planet more than it takes, to advance towards keeping its resource consumption within planetary boundaries, and therefore to strive to reduce its consumption footprint and double its circular material use rate in the coming decade" (EC, 2020). For citizens, this means that $C E$ will encourage recycling and provide new, circularity-based products and services. However, there also exists a much more fundamental need for citizens to alter their consumption processes,

\footnotetext{
* Corresponding author.

E-mail address: angelina.korsunova@helsinki.fi (A. Korsunova).
}

rethink needs and values and build up knowledge and new skills. From a policy perspective, it is critical to understand these shifts and how citizens envision being part of the CE. These insights will better support the design of a just and efficient framework for the $\mathrm{CE}$. Thus, the $\mathrm{EC}$ has recommended including the $\mathrm{CE}$ as a regular theme of citizens' dialogues (EC, 2020).

As a concept, CE is characterized by strong practitioner-driven approaches and a lack of scientific consensus reflected in the multiplicity of competing academic definitions (Kirchherr et al., 2017; Reike et al., 2018). Whereas the majority of definitions still center on technological processes and business strategies, it is becoming increasingly evident that citizen-level perspectives are critical for supporting the transformation to a more circular future (Hobson, 2016). For example, a recent study identified consumers' lack of interest and awareness of $\mathrm{CE}$ as among the top barriers to $\mathrm{CE}$ implementation, as reported by businesses and policymakers (Kirchherr et al., 2018). Also, De Jesus and Mendonça (2018) acknowledged that general inertia, existing consumer habits and a lack of awareness towards all possible CE choices are important 
reasons for the slow diffusion of CE models (De Jesus and Mendonça, 2018). On the micro-level of CE, most literature is dedicated to businesses and firms as active agents in CE and to their skills and capabilities for operating within it (e.g. De los Rios and Charnley, 2017). Surprisingly little attention has been given to the specific roles of citizens as enablers of the CE (Maitre-Ekern and Dalhammer, 2019) or to the skills and competences relevant for its future. Due to its growing popularity, a lack of clarity and narrow practical enactment, the concept and its operationalization require analytical and empirical attention (Lazarevic and Valve, 2017).

Although CE is assumed to bring economy-wide system transformations, the vision of circular citizens as recyclers and consumers remains rather traditional and unaspiring. The purpose of our study is to enrich the citizen-level perspective on CE and tap into a wider range of potential citizen roles for CE transformations. We challenge the assumption that the biggest contribution of citizens to a CE is that of passive consumers, ready to switch to the new markets of recycled goods. In particular, we explore the perceptions of young adults in Finland on how the CE reflects into their everyday lives. Considering the long-term systemic changes that a CE requires, it is important to consider the potential for change in young adults, which is still quite under-researched (Francis \& Davis 2015). In fact, this phase of life is important for understanding sustainability transitions for at least two reasons. First, young people are important agents in sustainability transitions: they make multiple consumption decisions either themselves or through their families (Collins 2015; Hill 2011), and they are future adults. Second, adolescence is an important phase in which values are being formed (Flanagan 2003). For example, there is evidence that pro-environmentalism, such as recycling, decreases (Krettenauer, 2017) or dips (Olsson \& Gericke 2016) during adolescence. In general, young people tend to be reluctant to accept personal responsibility for the environment and assign responsibility to government institutions (Wray-Lake et al., 2010). Adolescents' perceptions of social responsibility are strongly influenced by their social environments (Wray-Lake et al. 2016), suggesting that sustainability education in schools plays a key role in shaping their perceptions of sustainable behaviors and roles in sustainability transitions.

Korhonen et al. (2018) suggested that to advance the CE it is central to develop and focus on systems approaches to the cooperation of producers, consumers and other societal actors. Yet explorations of such cooperation and interaction and what the cooperation could potentially entail are scarce in the literature. By examining the perceptions of CE among young adults in Finland, not only do we extend the notion of the citizen role in CE, but we also develop implications for cities, policymakers and businesses in advancing the transition towards the CE together with citizens.

Next, we introduce the theoretical framing for our analysis, reviewing the roles traditionally assigned to citizens in the CE. Then, we go on to present our empirical materials and how we have made sense of the data using content analysis. Further, we show the results of our analysis and discuss them in relation to previous research.

\section{Literature background}

The concept of CE has been repeatedly criticized for its lack of focus on the social dimensions of sustainability (Murray et al., 2017; Geissdoerfer et al., 2017). For example, not enough attention has been paid to issues of social equity and equality in CE implementation (Millar et al., 2019; Kirchherr et al., 2017). Moreover, it has been largely ignored that the fundamental purpose of the economy is to improve citizens' well-being (Seyfang, 2004). Thus, it is important to reflect on how the transition to a CE would contribute to the well-being of citizens and how it would translate into everyday life. In practice, hardly any studies address the potential of CE to improve the well-being of citizens. In this regard, instead of an exclusive focus on having, it is more useful to connect to the full variety of fundamental human needs, including the needs for belonging, participation, creation/experimentation, identity, freedom and idleness (Max-Neef, 1991). This approach enables understanding how and why being an active citizen and doing purposeful activities is fulfilling and contributes to well-being (Michaelis and Lorek, 2004).

The mainstream CE discussion is very unimaginative regarding the citizens' roles, and rather sticks to the familiar mundane citizen activities typical of the linear economy (Hobson, 2016). Thus, the current $\mathrm{CE}$ vision for citizens is about being responsible consumers (choosing CE products vs conventional) and efficient recyclers (sorting and returning recyclables to the designated collection points). Indeed, this is also visible in the subsequent attempts of different authors to operationalize circular activities and behaviors at the citizen level.

For example, Camacho-Otero et al. (2020) discussed circular behaviors throughout the consumption process and came up with nine activity types for its different stages. The first stage - acquisition - is associated with re-buying, renting and receiving. The next consumption stages (appropriation, appreciation, devaluation and divestment) are related to retaining goods, repairing (or maintaining them) and remunerating them (renting out or sharing). The last consumption stage is disposition, associated with returning, reselling or relinquishing goods. All these activities make sense in relation to the consumption of goods, and the classification also establishes links from being a consumer to being a user of goods. However, its focus on the consumption process implies that any behavior unrelated to the use or consumption of goods has no meaning in the $\mathrm{CE}$.

Maitre-Ekern and Dalhammer (2019) observed that in the context of the $\mathrm{CE}$, citizens are interchangeably referred to as "consumers", "users" and, sometimes, as "peers" (related to sharing). Also, the Ellen MacArthur Foundation (2013) has previously emphasized that in the $\mathrm{CE}$, consumers would gradually transform into users. Yet this still means that citizens are expected to behave as well-informed individuals while making their purchasing decisions; for example, they may choose to purchase services instead of goods. While reviewing EU policy documents and other official sources, Maitre-Ekern and Dalhammer (2019) put together a categorization of all the roles and activities expected of citizens in a CE. Although the list of activities is rather diverse, the authors differentiate between six citizen roles: purchaser, maintainer, repairer, seller, sharer/collaborator and sorter/recycler. Indeed, these roles reflect the development that has occurred in perceiving citizens not just as consumers, but also as more active participants in the economy (i.e. in trading and exchanging goods). Moreover, the roles of maintainer and repairer convey the idea that citizens have the potential to contribute positively to the life of goods instead of being mere "consumers" who are using up resources. However, Maitre-Ekern and Dalhammer (2019) acknowledged that these roles will most likely evolve and that their initial mapping is subject to updates. Similarly to repairing, it is worthwhile to consider other activities that might add value instead of use it up, e.g. upcycling. Bridgens et al. (2018) described upcycling as the reuse of materials by individuals, resulting in an increase in value. The authors explained that upcycling can be driven both by the necessity to meet basic human needs (e.g. making a sleeping place out of whatever is at hand) and the need to be creative and experimental, to make crafts and create art objects. Either way, upcycling increases the value of objects or materials, and widens the traditional perceptions of citizen roles in a CE.

While the $C E$ is frequently operationalized as a combination of the core circularity principles: reduce, reuse and recycle ac- 
tivities (the 3Rs, Ellen MacArthur Foundation, 2013), there exist many more combinations of Rs with reference to CE. In their study, Reike et al. (2018) did not only find varying numbers of Rimperatives, such as 3Rs, 4Rs or 6Rs, but also different meanings assigned to the same Rs, which implies that contradictory conceptualizations are being used. In fact, they found 38 different restarting words ${ }^{1}$ in varying combinations in the context of CE. Essentially, the Rs represent different value retention strategies for resources in the $\mathrm{CE}$, but the same $\mathrm{R}$ translates into completely different actions for different actors, and only a limited set actually applies to the citizen context. As suggested by Reike et al. (2018), only the following apply to citizens: refuse, reduce, reuse, repair and recycle.

The $R$ of recycling seems to be the most prominent activity in literature and in practice. For instance, Gregson et al. (2015) suggested that the enactment of a CE is still "limited and fragile" and mostly put into practice through global recycling networks. In their systematic literature review on the $\mathrm{CE}$ initiatives of the $\mathrm{EU}$, Mhatre et al. (2020) established that recycling has been the most widely used circular strategy. At the citizen level, CE studies often focus on household waste management and the willingness to sort and recycle according to official guidelines (e.g. Nainggolan et al., 2019). In the context of developing countries, studies also bring forward the efficiency and positive impact of informal recycling by citizens for climate change mitigation (e.g. Vergara et al., 2016; UNEP, 2013). While it is indisputable that citizen recycling constitutes an essential part of the CE, insufficient attention is being paid to the other Rs. For example, Gusstrand Edbring et al. (2016) highlighted that enabling a CE requires consumer willingness and acceptance to switch to different models of consumption, yet too little is known about consumer attitudes towards, e.g., being active in reuse (reselling, renting, leasing and sharing). Further on, Suarez-Eiroa et al. (2019) proposed that a new consumption culture is needed within the CE; this not only demands the production of more sustainable goods, but is also less focused on affluence and ownership. In this sense, the 5R typology allows dissociating consumption and the role of citizens in a $\mathrm{CE}$, which brings the focus back onto the ultimate goal of a $C E$ - resource value retention rather than an increased consumption of CE products and services. For example, the $\mathrm{R}$ of refuse emphasizes that citizens may choose to buy less and try to minimize the use of packaged goods or free goodies in an explicit effort to prevent waste generation. The $\mathrm{R}$ of reduce is associated with using purchased products less frequently, using them with more care and longer or using certain services less frequently. Obviously, there are overlaps between the Rs, but the advantage of the 5R typology for citizens is its capacity to portray citizens as individuals with active positions in a CE.

Beyond the CE discussion arena, there have been attempts to draw attention to citizens as active participants in the economy. For example, the term "prosumer" has been utilized to describe consumer participation in the innovation processes of companies, acknowledging their involvement in "co-producing" the goods or services. Ritzer et al. (2012) observed that although prosumption has always existed, the rise of the ICT and social networking have expanded the magnitude of prosumption. In the context of a $\mathrm{CE}$, collaborative consumption can for example manifest itself through individual-level upcycling of plastic waste (Zhong and Pearce, 2018), citizen's engagement in smartphone de-

1 [1] In alphabetic order these are: re-assembly, recapture, reconditioning, recollect, recover, recreate, rectify, recycle, redesign, redistribute, reduce, re-envision, refit, refurbish, refuse, remarket, remanufacture, renovate, repair, replacement, reprocess, reproduce, repurpose, resale, resell, re-service, restoration, resynthesize, rethink, retrieve, retrofit, retrograde, return, reuse, reutilize, revenue, reverse and revitalize.
Table 1

Distribution of respondents by gender

\begin{tabular}{llll}
\hline & Female & Male & Not stated \\
\hline Number of students & 163 & 84 & 2 \\
\hline
\end{tabular}

Table 2

Distribution of respondents by age

\begin{tabular}{ll}
\hline Age (years) & Number of students \\
\hline 16 & 117 \\
17 & 87 \\
18 & 39 \\
19 & 4 \\
20 & 2 \\
& Total: $\mathbf{2 4 9}$ \\
\hline
\end{tabular}

sign (Hobson, 2016) or consumers giving a second life to their things through second-hand shops (El Mahmoudi et al., 2019).

Stern (2000) distinguished between different types of proenvironmental behavior and emphasized that besides the everyday behaviors in the private sphere (such as the use of public transport, saving energy, water, etc.), environmental activism represents a way for citizens to influence the public sphere. Participation in environmental demonstrations, public clean-ups or membership in waste prevention oriented grass-root movements, such as Zero Waste, are among citizen activities that can help to advance the transition to a CE. Moreover, these type of activities create interaction possibilities between citizens, policymakers and businesses. The Voluntary Simplicity Movement can also be seen to relate to the broader context of environmental activism. Voluntary simplicity, which is a diverse social movement resisting consumerist lifestyles (Alexander, 2013), can be motivated by not only a desire for more time, but also, e.g., environmental concerns and an aspiration to reduce environmentally damaging practices. Moreover, with regard to well-being, voluntary simplicity has been observed to have a significant positive relationship with satisfaction with life (Boujbel and d'Astous, 2012).

Having reviewed the literature on citizen roles and activities in a CE, we build on the 5R framework of Reike et al. (2018) and combine it with other conceptualizations of citizen roles to analyze the perceptions of the $\mathrm{CE}$ in young adults in the Finnish context.

\section{Materials and method}

For the purpose of exploring the CE perceptions of young adults in Finland, we reached out to Finnish high schools. The age of high school students in Finland is generally between 15 to 20 years. After the compulsory nine year comprehensive school, students continue to the upper secondary level and choose between general and vocational education at approximately 15-16 years of age. High school takes about three years to complete, and after passing a national school-leaving matriculation examination, students are eligible to apply for further studies at universities, universities of applied sciences and vocational institutions (Finnish Ministry of Education and Culture, 2020). Altogether, our dataset consists of 249 responses from high school students. Females and 1-2 year students were better represented among the respondents (Tables 1 and 2).

Although at that stage, young adults are most often living with their parents, they represent an interesting group. They are active users of the internet and social media, follow social trends and seek for information independently as they consider and plan their life paths for after high school. Although they do have personal interests, they are not yet directly affected by the traditions and ways of thinking of study disciplines, as often happens during university studies. 
Table 3

Open-ended questions for exploring students' perceptions of the CE in their daily lives

Questions presented to students
1. What does a circular economy mean?
2. How does the circular economy relate to your everyday life?
3. How does the circular economy relate to the everyday activities of people?
4. How could you be more active in the circular economy?

This research was implemented in collaboration with five high schools from different urban and semi-urban environments in Finland to account for potential differences in schooling and living. The collaboration consisted of online workshops given by university researchers to high school students on the topics of sustainable consumption and CE during the spring semester 2020. The workshops were part of the regular school lessons, which were taking place online due to the COVID-19 pandemic. Each workshop lasted $1 \mathrm{~h} 15 \mathrm{~min}$.

At the beginning of the workshops, the students were asked to complete an online questionnaire with four open-ended questions (Table 3). The students were generally given 10-15 minutes to complete the questionnaire. Although they had every possibility to look up definitions and answers online, the questions were designed to probe personal understandings of $C E$ in daily life activities. The students were informed that all answers would remain anonymous and would not be evaluated in any way. The participants were encouraged to express their personal opinions rather than textbook answers. The students took part in the workshops from their own homes, and their participation in the questionnaire was not monitored in any way. As the questionnaire was distributed at the beginning of the workshop, the content of the workshop did not influence student responses.

The responses to each question varied from a few words to several sentences. As the questions were rather similar in content, in our analysis, we treated each student's responses to all four questions as one mini-interview, which was utilized to achieve a deeper understanding of the meanings and perceptions. In other words, we treated our data as a set of 249 mini-interviews and employed content analysis (Mayring, 2004; Krippendorff, 2004) to explore what CE means to high school students in their daily lives. All data was collected and analyzed in Finnish, to ensure the correct interpretations of the perceptions.

For the analysis, the members of the research team first read through the same set of 77 responses (representing 30\% of the dataset) and wrote down suggestions for the initial coding scheme. After that, the researchers compared their schemes and, within several iterations, developed a joint scheme for coding. The resulting coding scheme is a combination of inductive and deductive approaches: although the scheme was initially grounded in the data, the researchers also used CE literature to make meaningful theme categories to make sense of the findings in the context of CE. For example, the $5 \mathrm{R}$ framework inspired some of the theme categories in the scheme. Next, the research team members were assigned specific parts of the dataset for coding. All researchers coded and analyzed the data using Nvivo 12, a qualitative analysis software. If new codes emerged during this process, the researchers added them to the joint coding scheme. The coding took place in close collaboration and through reiterative discussions over a period of one month.

\section{Results}

Our findings are organized around nine themes, which emerged from the content analysis of the high school students' responses (Table 4). In addition to the 5Rs applicable to citizens, as de- scribed by Reike et al. (2018), additional topics related to sustainable consumer behavior, education, nature and CE as industrial solutions emerged. Each of the themes contains several subtopics as depicted in Fig. 1. In the following, we will first describe the quantitative findings related to each of the nine themes and then delve into the qualitative insights related to $\mathrm{CE}$ activities, perceptions and resulting roles. Apart from the more traditional roles described in the literature, such as consumer (of more sustainable/recyclable products), user/sharer, seller, repairer and recycler, we identified four more citizen roles relevant for a $C E$. These are: upcycler, thrifter, expert/learner, and conservationist.

\subsection{From recycling to education - emerging themes from the student responses}

From the quantitative findings, the broader theme of recycling was by far the most prevalent one (see Table 4). Within the theme of recycling, there were different topics related to recycling in general (e.g. "recycling is a big part of life"), careful/attentive sorting and the return of sorted waste to designated collection points. Thus, students strongly associated CE with recycling activities and recycling schemes for household waste management, which agrees with previous literature. In many cases, recycling was mentioned more than once by the same respondent, as evident from the number of mentions in Table 4. It should be noted that in our analysis, we separate between recycling activities performed by individuals and references to recycling as an industrial process performed by companies. It was important to make this distinction to reflect on how the respondents saw recycling as part of their everyday life and not someone else's responsibility. Thus, the industrial perspective on recycling is reflected in a separate theme, entitled "CE as industrial solutions" (94). This theme refers to the various industrial processes and solutions to prolong the use of materials and maximize their value.

Reuse was the next most popular theme. A large number of different topics from the dataset emerged as related to reuse, e.g. buying second-hand, re-selling, donating, passing on (to relatives and friends), borrowing, renting, sharing and repurposing. However, this theme is not homogeneous in how the responses are distributed across the different topics. For example, second-hand shops ("kirpputorit" in Finnish) were mentioned 72 times, while mentions of renting and sharing only amounted to 5-6 times each. Also, buying used was equally popular (72), while re-selling was mentioned 39 times. Donating and passing on appeared in about 10 responses each, while the activity of repurposing came up in 13 answers.

Roughly about one-fifth of the respondents mentioned topics related to the themes of reduce and refuse. The majority of responses within the reduce theme were about avoiding the waste of something and avoiding single-use items. Under the refuse theme, the responses were mostly about avoiding buying unnecessary things. The theme of repair emerged as the least popular one (27) among the Rs of the dataset. Besides the repair itself, it also includes topics such as maintenance and upcycling, which were only seldom mentioned. 
Table 4

Overview of the frequencies for coding and by persons

\begin{tabular}{lll}
\hline Theme & Number of mentions (codes) & Number of persons \\
\hline Recycle & 408 & 238 \\
Reduce & 44 & 40 \\
Refuse & 58 & 54 \\
Repair & 27 & 26 \\
Reuse & 233 & 151 \\
Sustainable consumer behavior & 88 & 58 \\
Nature & 40 & 38 \\
Education & 15 & 15 \\
CE as industrial solutions & 94 & 86 \\
\hline
\end{tabular}

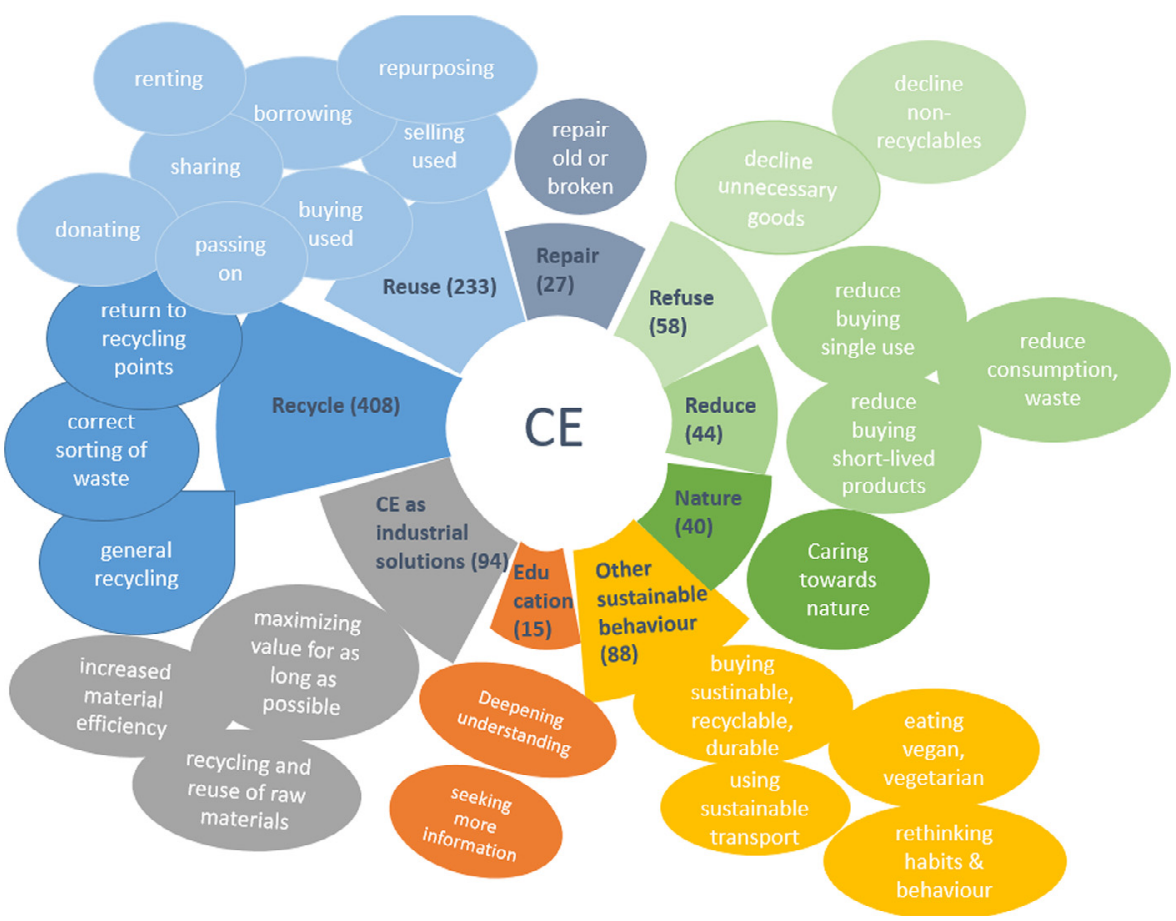

Fig. 1. Operationalizing CE for everyday life - as perceived by young adults in Finland.

In addition to the Rs, many topics related to other types of sustainable consumer behavior (88) came up. For example, the purchase of sustainable, recyclable and/or durable products was mentioned 51 times. Other topics included under this theme were the use of public transport, meat-free diets, the reconsideration of one's own consumption habits and the use of renewable energy.

Under the theme of nature, we grouped all responses that explicitly connected the $\mathrm{CE}$ with natural resources and environmental issues (e.g. climate change or environmental degradation). For example, one of the respondents described the CE as "an economy that enables saving nature".

The theme of education is represented modestly in the dataset (15 responses), but it still emerged as a distinct theme of its own. For example, it includes responses dealing with the need to self-educate and learn more about the $\mathrm{CE}$ in order to be better equipped as a circular citizen.

Out of 249 responses, seven answered "do not know" to every question. Also, four respondents showed signs of irritation, fatigue or indifference to the topic of CE. For example, some responded that " $C E$ does not show in my life in any way, but I really haven't paid any attention in my life to CE", or "I don't know and don't even have the interest to think about it". Nevertheless, we consider these responses valid, since students took the time to enter them into the questionnaire.
4.2. Extending the notion of citizen role in the CE: upcyclers, thrifters, expert/leaners, givers and conservationists

As a next step in our analysis, we further scrutinized all nine themes to translate them into explicit citizen roles. Certain themes, such as recycling, have an obvious connection to a dominant role - in this case, "recycler". But in fact, many of the themes actually translate into multiple citizen roles. For example, the reuse theme has connections to the roles of seller and user/sharer (Maitre-Ekern and Dalhammar, 2019). Table 5 illustrates with quotes how multiple roles can be identified within one theme.

The traditional "consumer" role is evident through numerous themes: e.g. reuse, sustainable consumer behavior and even education. For instance, the theme of reuse was dominated by examples of shopping second-hand as one of the good examples of CE activity. Moreover, buying sustainable, recyclable and/or durable products was also the most popular topic within the theme of sustainable consumer behavior. Finally, students also mentioned the need for self-education in connection to being able to make more informed purchasing decisions. On the other hand, we found the roles of "seller" and "user/sharer" to be relevant only under the theme of reuse.

Beyond these previously explored roles, we especially want to bring forward the roles that emerged from our dataset. Building on the role of "repairer", we also identified the "upcycler" role under 
Table 5

Emerging themes, topics and citizen roles from perceptions of CE by young adults

\begin{tabular}{|c|c|c|c|}
\hline Theme & Topics & Sample responses & $\begin{array}{l}\text { Citizen } \\
\text { roles }\end{array}$ \\
\hline \multirow[t]{3}{*}{ Education } & $\begin{array}{l}\text { Deepening learning and } \\
\text { understanding }\end{array}$ & $\begin{array}{l}\text { - By first learning more about the topic, so that I could know what all things are part of } \\
\text { it, and afterward being able to act better; } \\
\text { - By becoming a circular economy researcher; } \\
\text { - By finding out more about the subject; } \\
\text { - Finding out what goods are impossible to recycle and try to avoid buying them. }\end{array}$ & $\begin{array}{l}\text { Expert/Learner } \\
\text { Consumer }\end{array}$ \\
\hline & $\begin{array}{l}\text { Seeking more information and } \\
\text { encouragement }\end{array}$ & $\begin{array}{l}\text { - I don't know how I could participate more [to CE], but if I knew more about things, I } \\
\text { could do those that help circular economy; }\end{array}$ & $\begin{array}{l}\text { Expert/Learner } \\
\text { Consumer }\end{array}$ \\
\hline & & $\begin{array}{l}\text { - In the shops more info about the materials goods are made of and their carbon } \\
\text { footprints. People are encouraged to recycle and in schools there is also teaching for } \\
\text { such skills; } \\
\text { - Circular economy is visible in everyday life in the form of recycling, but also that there } \\
\text { is more discussion about climate change, especially in the social media and media } \\
\text { includes a lot of circular economy related news and things. }\end{array}$ & Recycler \\
\hline \multirow[t]{3}{*}{ Recycle } & Sorting waste & $\begin{array}{l}\text { - Putting garbage to the right bin; } \\
\text { - I sort garbage; } \\
\text { - I also sort plastics for recycling; } \\
\text { - At home we sort energy waste, plastics, cardboard, glass jars, etc. }\end{array}$ & Recycler \\
\hline & $\begin{array}{l}\text { Returning to } \\
\text { recycling points }\end{array}$ & $\begin{array}{l}\text { - I return bottles; } \\
\text { - In my everyday life circular economy is when I take something to recycling points; } \\
\text { - In the city there are different recycling points; } \\
\text { - In the cities there are big recycling centers where sorted garbage can be returned. }\end{array}$ & \\
\hline & General recycling & $\begin{array}{l}\text { - By recycling garbage; } \\
\text { - Recycling the things you buy or get in the right way, so that they could be } \\
\text { re-circulated again; } \\
\text { - Something related to recycling; } \\
\text { - Recycling is a big part of life. }\end{array}$ & \\
\hline \multirow[t]{2}{*}{ Reduce } & $\begin{array}{l}\text { Reducing buying } \\
\text { single use } \\
\text { products } \\
\text { Reducing buying } \\
\text { short-lived products (e.g. fast- } \\
\text { fashion) }\end{array}$ & $\begin{array}{l}\text { - Give up single-use products; } \\
\text { - Forget about the concept of single-use; } \\
\text { - Avoiding single-use products. } \\
\text { - I could reduce buying fast-fashion; } \\
\text { - Avoiding easily-breakable fast-fashion - clothes; } \\
\text { - I could try not to buy new clothes so often. }\end{array}$ & Thrifter \\
\hline & Reducing & $\begin{array}{l}\text { - Reduce consumption; } \\
\text { - I don't use water in vain; } \\
\text { - I could reduce my food waste; } \\
\text { - We don't waste electricity or anything else; } \\
\text { - I could think more about what I buy and buy with consideration. }\end{array}$ & Simplifier \\
\hline \multirow[t]{3}{*}{ Refuse } & Declining non-recyclable & - Finding out which things are impossible to recycle and not buying those; & $\begin{array}{l}\text { Thrifter } \\
\text { Simplifier }\end{array}$ \\
\hline & products & - Thinking about what you really need and use and how easy it is to recycle it. & \\
\hline & $\begin{array}{l}\text { Declining unnecessary } \\
\text { products }\end{array}$ & $\begin{array}{l}\text { - I consider what I buy based on how long it is of value to me, so that it doesn't end up } \\
\text { in waste; } \\
\text { - I refuse to buy unnecessarily new stuff; } \\
\text { - Considering what I really need and buy only that, used; } \\
\text { - I could reduce my consumption more, for example in clothes and impulse purchases. }\end{array}$ & \\
\hline \multirow[t]{2}{*}{ Repair } & Repairing old or & - I always try to repair broken things; & $\begin{array}{l}\text { Repairer } \\
\text { Thrifter } \\
\text { Upcycler }\end{array}$ \\
\hline & broken things & $\begin{array}{l}\text { - Fixing slightly broken things by your own; } \\
\text { - Repairing clothes by your own; } \\
\text { - I could learn how to repair and tune my own clothes better; } \\
\text { - If a piece of clothing breaks, it will be fixed. }\end{array}$ & \\
\hline \multirow[t]{3}{*}{ Reuse } & Buying used & - Buying old high school books; & $\begin{array}{l}\text { Consumer } \\
\text { Thrifter }\end{array}$ \\
\hline & & $\begin{array}{l}\text { - I buy clothes from flea markets; } \\
\text { - Nowadays used phones are repaired; and then sold for a cheaper price than if you } \\
\text { bought an entirely new phone; } \\
\text { - I buy used moped parts. }\end{array}$ & \\
\hline & Selling used & $\begin{array}{l}\text { - I bring things to the flea market; } \\
\text { - Clothes that are too small for use, we either sell ofrdonate; } \\
\text { - We sell unnecessary stuff at the flea market; } \\
\text { - I sell my old clothes, so that I wouldn't have to throw them to waste; } \\
\text { - Selling for example in flea markets or in the internet those clothes and items, that I } \\
\text { don't need. }\end{array}$ & Seller \\
\hline
\end{tabular}


Table 5 (continued)

\begin{tabular}{ll} 
Theme & Sample responses \\
& \\
\hline Borrowing/sharing & - People recycle, share and lend their own things; \\
& \\
& - Instead of producing and throwing away things, one would focus on borrowing or \\
& lending, renting or sharing; \\
& - Must we own everything ourselves, if we could borrow the things from someone else?; \\
& - I borrow things from my friends; \\
& - People share. \\
& - Bringing our clothes to UFF [charity];
\end{tabular}

- Bringing our clothes to UFF [charity];

- Giving clothes to someone else and getting used clothes from other people;

- Giving old things to those who need them; which you don't need yourself;

- I recycle unnecessary stuff as well as possible, either to the flea market or as donations;

- I give my old clothes to my little sister;

- For example, I got from my older cousins their used clothes, which were too small for them.

Renting

- Renting stuff;

- For example, renting a car;

- If I need some stuff only once, I can either borrow it or rent it from someone else.

Repurposing

- People use for example bags and clothes made of plastic [waste];

- We can use again things and apply them for other purposes, for example of a broken thing you can use parts and use them for different purposes;

- You can for example return plastic bottles, which is used to make fabric.

- Clothes and linen are used to the end and then they can be made to something new, for example rags.

Other Using alternative

sustainable consumer behavior

transport (other than private car)

sustainable/

recyclable/ durable productsBuying

Eating vegan/vegetarian

Rethinking entire behavior

Nature

Caring towards

nature

Maximizing value for as long

CE as

industrial

solutions
- Bicycling instead of driving a car;

- I could avoid using car transport to reduce my carbon footprint;

- I try to travel buy walking, cycling or public transport and I travel quite little;

- Using city bikes;

- I use public transport a lot.

- I buy wooden pens for school;

- I buy good-quality and durable things;

- I could buy durable things instead of buying cheaper things that break easily;

- I could make different choices when I buy things;

- I could pay more attention to the production process and durability when I buy products.I buy things that last longer;

- I could avoid meat products and buy organic products;

- I don't eat meat;

- Even though I already am a vegetarian, I could reduce the amount of dairy products and try to become vegan;

- I could avoid eating cheese and eggs,

- My family has reduced eating red meat and increased eating chicken [...] Personally I have reduced eating red meat a lot, but I cannot become vegan.

- Considering different life choices several times (food, travelling, other consumption);

- Finding out first better about the topic [of CE], so that I know better what it means, and then act better;

- I could change my consumption to even more ecological and then finding out, what else I could do to make things better

- I would like to move into a small ecological house with a small consumption and which would work ecologically, and I would like to recycle,more and focus better on my own consumption.

- Improving the wellbeing of planet Earth;

- How can we mitigate climate change;

- We shouldn't just always take more from nature;

- We should make things more durable and make longer life cycles so that put as little strain on Earth and our nature as possible!

- The goal of CE is to maximize the value (benefits) of some good in all different phases;

- Maximizing the circulation time of goods in the economy;

- The producer tries to maximize value of the good.
Giver/Benefactor

User/Sharer

Upcycler

Thrifter

Conservationist

Consumer

Ex-

pert/Learner

Conservationist

\section{Thrifter \\ Ex- \\ pert/Learner \\ Conserva-}

tionist

Conservationist

(continued on next page) 
Table 5 (continued)

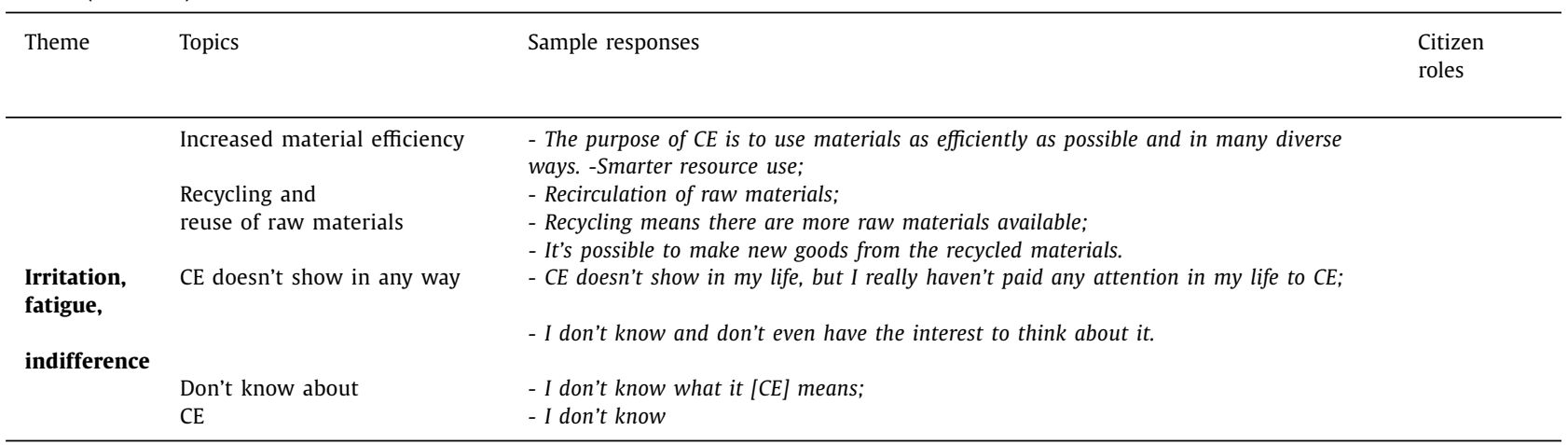

the theme of repair. For instance, repairing clothing can become a creative process if one aims to make a piece of clothing not only functional again but also trendier: "I could learn how to repair and pimp up my own clothes". Upcycling is also relevant under the topic of repurposing: "We can use again things and apply them for other purposes, for example of a broken thing you can use parts and use them for different purposes". The "upcycler" role can satisfy some basic human needs, but it also connects with the human need to be creative and build up identity. However, just as repairing, upcycling requires specific skills, time and possibly special equipment.

In connection to the themes of reduce, refuse and other sustainable consumer behavior, we identified the role of "thrifter" when one consciously makes the decision to be reasonable in consumption, avoid wasting, be conserving and smart about one's own belongings and perform maintenance activities to prolong the life of their possessions. The role of thrifter also assumes being a more critical/analytical consumer to enable the shift towards the new consumption culture, less focused on affluence. Being thrifty and reasonable connects to the other themes, such as reuse and repair. For example, buying used objects is motivated by thriftiness: "Nowadays, used phones are repaired and then sold for a cheaper price than buying an entirely new phone". Repairing things on their own also makes sense to thrifters as a more economical option: "Fixing slightly broken things by yourself". In many ways, the role of thrifter is similar to what has been previously described in the literature as "voluntary simplifier". However, not all thrifters are voluntary simplifiers: although thrifters might have environmental values, they are less ideological and rather respond to financial motivations and rewards. In the context of the CE, this has important implications for directing behavior through deposit systems, tax breaks and pricing strategies for refurbished/recycled goods.

The role of "expert/learner" is about aspiring to know more about the $\mathrm{CE}$, to achieve a deeper understanding of the system and how to take a more active part in it. The expert/learner role emerged most strongly within the theme of education, but it is also related to the theme of sustainable consumer behavior. Although it comes close to being a "savvy consumer", this role is wider, as it extends beyond consumption: "By first learning more about the topic [CE], so that I could know what all things are part of it, and afterward being able to act better". The interest of expert/learners in the subject is not always professional (they do not necessarily become researchers or CE experts): they are driven by their active attitudes and curiosity. Expert/learners have a great potential to influence peers, as today, there are many examples of bloggers who reflect on their issues of interest on social media, attracting followers. This role is also reflective of the human need for self-realization and development, of the need to understand the world around us and to be understood by others.

While examining the theme of reuse, it was evident that besides the roles of seller and user/sharer, there is also the "giver/benefactor". Donating clothing, toys, furniture and homeware has always been part of the society, yet in the context of CE it gains new importance for the sake of the most efficient recirculation of goods and the retention of their value. The activities of donating and passing on are at the core of the role of giver/benefactor, although they are not the same. Usually, passing on things requires more effort, planning and care from the original owner than donating. Often, donating is about the effort of packing things and bringing them to the facility (designated containers or organizations). In the case of clothing, for example, passing on might require a more careful analysis of the items' condition and sorting by size and suitable gender colors. The role of giver/benefactor has a dual motivation: although at the heart of it is the idea of benefitting others and not letting items in good condition go to waste, it is also a way to free up space for new items and proliferate consumerism. Still, the giver/benefactor role has important connections to human well-being and the need to participate: it is a way to contribute to societally meaningful activities.

Finally, "conservationist" is a role that came up via the theme of nature. Although in the dataset, the CE was often initially described as a system of industrial solutions, its connection to nature as the ultimate reason for a renewing economy emerged from the student responses: “We shouldn't just always take more from nature". This role reflects how nature is part of human values and a significant contributor to human well-being, as the positive health impacts of spending time in nature have been long recognized. Thus, having nature at the core of our thinking and not the prospects of achieving more growth is what should enable the transition to a CE.

\section{Discussion}

Our study has examined how young adults in Finland perceive the connection of the $\mathrm{CE}$ to their everyday lives. Among the themes that emerged from the student responses, it is evident that recycling and reuse are the dominant ways of operationalizing the CE in everyday life. The familiar roles of recycler and consumer (even if of second-hand goods) are what students mostly connect to being active in a CE. Despite the fact that our respondents are young adults and therefore represent the generation of "digital natives", the ICT-enabled reuse activities of renting, borrowing and sharing were hardly mentioned at all. In other words, access-based ways of consuming are not yet the "new normal", and their uptake is going slower than hoped. This is in line with earlier research that has shown that for a number of reasons (desire to own, lack of trust, safety doubts, etc.), access-based consumption is not yet that popular, even among young adults (Gullstrand Edbring et al., 2016). 


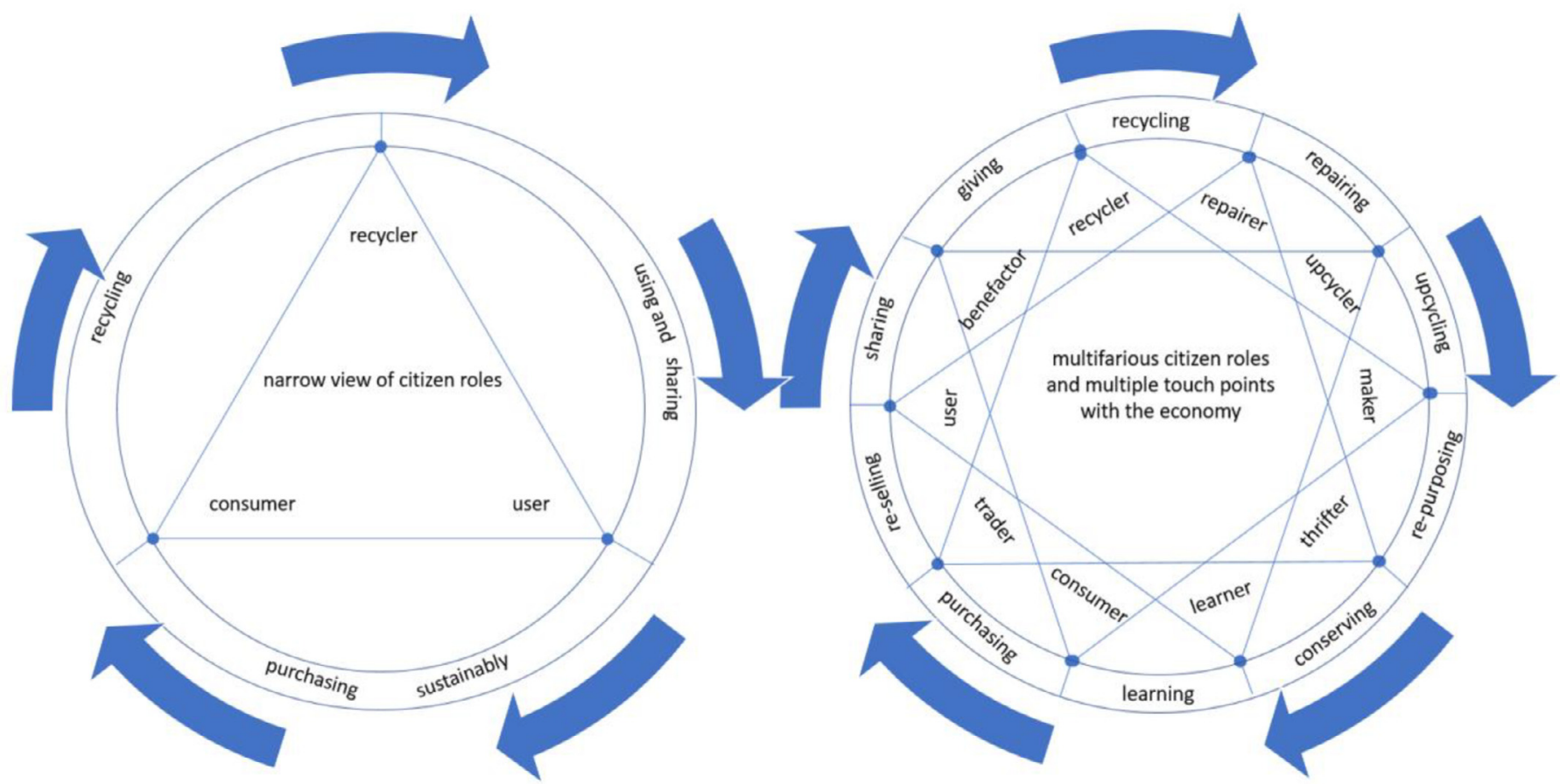

Fig. 2. From a narrow consumer-centered view to a multifarious set of citizen roles in a circular economy

At the same time, a surprisingly notable number of students related $C E$ to the strategies of reduce and refuse, recognizing the need to buy less and focus on reconsidering the existing habits and ways of living. This is an important finding with regards to the need to develop a new, less affluence-focused consumption culture, as proposed by Suarez-Eiroa et al. (2019). It also reflects the acceptance and realization of the students that the new economic system will be less driven by consumption. Yet, the findings also indicate that it is not apparent to the students what their roles in the new economic system might be, if not consumers and recyclers. For example, the activities of repairing, maintaining and upcycling were barely present among the responses. It is possible that the students simply did not perceive these activities as valuable and influential in a CE, and did not realize their potential to contribute to more circular lifestyles. As Hobson (2016) pointed out, the CE offers us an opportunity for more creative thinking on what our needs are and how we could satisfy them in alternative ways.

Thus, after analyzing student perceptions of CE in everyday life, we highlight the unobvious roles that have important implications for citizen well-being, cities and businesses in a CE. We propose that recognizing a more diverse range of citizen roles in a $\mathrm{CE}$ more accurately reflects the potential of citizens' interaction with the economy via multiple touch points (Fig. 2). For example, the upcycler role offers possibilities for citizens to slow down the material flows while also reconnecting with the fundamental human need for being creative and experimental (Max-Neef 1991). Moreover, upcycling has the potential to create new interactions between businesses and citizens if businesses take on the challenge of designing and packaging their products with creative reuse in mind (Bridgens et al., 2018). Certain brands, such as IKEA, have been fighting and even suing citizens for years for the creative hacking of their signature products, before realizing that it is more fruitful to connect with these hacker communities. As activities such as upcycling and repairing often require tools and space, there is a need to make them more accessible through, for example, schools and libraries. In practice, what happens sometimes is that during high school, students no longer have any craft lessons as part of the curricula: therefore, as they become older, the external encouragement for being creative and engaging in making is virtually non-existent.

Although the role of thrifter may seem like a feature of an individual's character, in today's reality it is a citizen role to be trained. Martins (2016) observed that neoclassical economics has erroneously taught us to perceive well-being in terms of given subjective preferences, ignoring the human capacity to grow personally and spiritually, revising preferences. Brown and Vergragt (2016) suggested that to initiate an evolution in society, a collective reframing of the idea of a good life is necessary. In other words, while we have been educated into consumers in a matter of decades, it is also possible to teach a different citizen model by training the skills of a thrifter. This would require opening up the well-being discussion in educational institutions on all levels. As Brown and Vergragt (2016) argued, many changes are already taking place, e.g. the diminishing interest in suburban life in favor of cities, when people chose to live in tighter spaces but with closer connections to various cultural activities and the renewed interest in activities such as community gardening. However, acceleration through education is needed in transforming affluence-focused attitudes. Training the thrifter role is about discussing more what waste is and what impacts different types of waste have on the environment and learning about the strategies to prevent waste generation, and to prolong the useful life of goods.

The need for CE-tailored education and information is especially evident from the insights on the expert/learner role. As reflected in their responses, students actually felt uncertain about the way they could contribute more to the CE (beyond recycling and buying second-hand). Moreover, some of them felt that they would first need to better understand what types of products and materials are recyclable. While the "Eco-Design Working Plan 2016-2019" by the EC has committed to incorporating different circular requirements into the design of products, these requirements are actually related to a number of aspects: such as durability, possibility of repair, possibility to upgrade, possibility of disassembly, ease of reuse and recycling (Bovea et al., 2018). Educating about 
these different aspects and what they mean in practice is a completely new type of content. Although it is now entering the curricula of universities, it is vital to consider all generations, and especially those that are no longer in the official education system - how and when will they learn about the CE? Innovative approaches are needed to organize opportunities for the exchange of knowledge and skills between generations on CE activities. While older generations may have the skills for activities like repair, younger generations might be savvy about technology-enabled CE solutions for sharing and renting. Cities could strive to enable inter-generational exchanges, because they have a great potential for contributing to well-being through feelings of belonging, understanding and being a valued member of society (Giovannini et al., 2007).

As for the role of giver/benefactor, more attention and discussion are needed to understand how different societal systems for donation of goods impact the CE. After the scandals related to the large humanitarian aid associations and dubious recycling schemes for clothing of well-known fast fashion retailers, societal distrust towards them has been growing. As the impersonal donation boxes for clothing provide little confidence that it will be useful to anyone, small scale citizen initiatives emerge in the social media, where citizens volunteer their time to manage online groups aimed at helping low-income citizens. Via such groups, people may ask for clothing of a certain size, personal hygiene items, food, furniture, etc., while others can choose to donate. This is related to perceived efficiency (Vicente-Molina et al., 2013), or in other words this phenomenon signals the need of citizens to have confidence in the efficiency of their benefactor activities. At the city level, more attention should be paid to organizing donation activities, as impersonal systems may, in some instances, lead to the acceleration of consumerism and CE rebound (Zink and Geyer, 2017), constituting an all-too-easy solution for dumping nolonger wanted items.

All too often, the CE is regarded as an innovative solution that will allow business-as-usual to continue while adding new business opportunities related to recycling. This weak interpretation of circularity also assumes the familiar apolitical role of the consumer or user of the new products and solutions for citizens (Johansson and Henriksson, 2020). However, one of the ways to evoke more reflexive and critical approaches towards the rhetoric of closing the loops is questioning not only the efficiency of circularity but also the need to strive for this efficiency. Even classical economic theory started out with Aristotle's ideas on human wellbeing originating in the harmonious use of existing commodities and not in the maximization of these commodities (Martins, 2016). The role of a conservationist is to bring the focus back to nature and its conservation, downshifting the appetites fueled with the promise of efficiency. U In fact In fact, reconnecting people with nature is one of the most powerful leverage points for sustainability transformations and a motivator for adopting sustainable behaviors in everyday life (Abson et al., 2017). Moreover, being in nature has positive impacts on human health and well-being (Keniger et al., 2013). Thus, it is essential to explore how cities could develop in a way that brings nature closer to citizens and what businesses could offer to fulfill this need.

While a merit of this study is illuminating the discrepancy between CE as a new economic paradigm and the lack of ambition or imagination for diverse citizen activities within this new paradigm, the present work is limited to exploring the views of young adults in Finland. This has direct implications for interpreting the results and designing future studies for other country contexts and various population groups. First, as Finland was among the first countries in the world to prepare a national CE roadmap in 2016, since then, systematic efforts have been made by the national innovation fund (Sitra) to integrate more content on CE into school-level education
(Sitra, 2019. Thus, young adults in Finland might be more knowledgeable about CE than in other countries. Second, while young adults are an interesting population group to study because their values are still forming and there is great potential to influence them via education, further insights could be obtained from other age groups. For example, income earners are highly relevant for exploring their perceptions of CE and its different value retention strategies (e.g. access-based consumption), while senior citizens could be a promising group for exploring the Rs of refuse and reduce (thrifting), and repair skills. Furthermore, comparing the CErelated perceptions, attitudes and skills of different age groups and in different country contexts (e.g. wealthier contexts and emerging economies) represent promising avenues for gaining a deeper understanding of the human dimension of $\mathrm{CE}$.

\section{Conclusions}

Young adults are important for sustainability transformations, as in that phase of life, they are more open to change and have wider access to various educational opportunities. In that sense, exploring their perceptions of the CE and its connection to everyday life has direct implications for shaping education and mapping out other means of support to transform consumers into more versatile $\mathrm{CE}$ citizens. Although the perceptions of $\mathrm{CE}$ by young adults in Finland turned out to revolve around the familiar activities of recycling and purchasing second-hand, additional insights - emerging especially from the themes of education, refuse, reduce and nature - have helped us to construct aspiring citizen roles in the CE. We highlight that these transformations should be guided by the ultimate goal of the economy to improve the well-being of citizens rather than by the prospects of new business opportunities. It is only by applying systemic thinking to CE activities and moving beyond the business-as-usual that real progress in the CE could be achieved. Focusing on stand-alone behaviors and barriers, such as the ones described for access-based consumption, will likely produce only suggestions for "minor fixes", as the diversity across the categories of goods and services is too vast. Tackling the issues more systemically requires concentrating on the well-being of the citizens and nature.

In our study, we explored the perceptions of young adults, although we emphasize that it is not so much the perceptions that need to be fixed, or at least not perceptions alone. Building collaborations and platforms for the interaction between different societal actors is necessary to embrace the $\mathrm{CE}$. Therefore, more research is needed into how CE policies and large initiatives translate into constellations of collaborations between different societal actors, which actors are consistently missing from these collaborations and what would be the ways to include them.

\section{Declaration of Competing Interest}

The authors declare that they have no known competing financial interests or personal relationships that could have appeared to influence the work reported in this paper.

\section{References}

Abson, D.J., Fischer, J., Leventon, J., Newig, J., Schomerus, T., Vilsmaier, U., von Wehrden, H., Abernethy, P., Ives, C.D., Jager, N.W., Lang, D.J., 2017. Leverage points for sustainability transformation. Ambio 46 (1), 30-39. doi:10.1007/ s13280-016-0800-y.

Alexander, S., 2013. Voluntary Simplicity and the Social Reconstruction of Law: Degrowth from the Grassroots Up. Environ. Values 22 (2), 287-308. doi:10.3197/ 096327113X13581561725356.

Boujbel, L., d'Astous, A., 2012. Voluntary simplicity and life satisfaction: Exploring the mediating role of consumption desires. J. Consum. Behav. 11 (6), 487-494. doi: $10.1002 / \mathrm{cb} .1399$

Bovea, M.D., Quemades-Beltran, P., Perez-Belis, V., Juan, P., Braulio-Gonzalo, M., Ibanez-Fores, V., 2018. Options for labelling circular products: icon design and 
consumer preferences. J. Clean. Prod. 202, 1253-1263. doi:10.1016/j.jclepro.2018. 08.180.

Bridgens, B., Powell, M., Farmer, G., Walsh, C., Reed, E., Royapoor, M., Gosling, P., Hall, J., Heidrich, O., 2018. Creative upcycling: Reconnecting people, materials and place through making. J. Clean. Prod. 189, 145-154. doi:10.1016/j.jclepro. 2018.03.317.

Brown, H.S., Vergragt, P.J., 2016. From consumerism to wellbeing: toward a cultural transition? J. Clean. Prod. 132, 308-317. doi:10.1016/j.jclepro.2015.04.107.

Camacho-Otero, J., Tunn, V.S.C., Chamterlin, L., Boks, C., 2020. Consumers in the circular economy. In: Brandao, M., Lazarevic, D., Finnveden, G. (Eds.), Handbook of the Circular Economy, eds.. Edward Elgar Publishing, Ltd.

Collins, R., 2015. Keeping it in the family: Refocusing household sustainability. Geoforum 60 (1), 22-32.

De los Rios, I.C., Charnley, F.J.S., 2017. Skills and capabilities for a sustainable and circular economy: The changing role of design. J. Clean. Prod. 160 (1), 109-122. doi:10.1016/j.jclepro.2016.10.130.

De Jesus, A., Mendonça, S., 2018. Lost in transition? Drivers and barriers in the ecoinnovation road to the circular economy. Ecol. Econ. 145, 75-89. doi:10.1016/j. ecolecon.2017.08.001.

EC (European Commission), 2019. Communication from the Commission to the European Parliament, The European Council, The Council, The European Economic and Social Committee and the Committees of the Regions - The European Green Deal. COM/2019/640 final.

EC (European Commission), 2020. Circular Economy Action Plan - For a cleaner and more competitive Europe. https://ec.europa.eu/environment/circular-economy/ pdf/new_circular_economy_action_plan.pdf

El Mahmoudi, F., Gaillard, J., Hendrickx, M., Min Suh, H., Spiessens, R., Vandamme, A-M., Nova Blance, J.R., van den Eede, A., 2019. Prosumers Everywhere: Investigating the Driving Forces Behind Prosumer Behavior in Different Socioeconomic Strata. Transdisciplinary Insights 3 (1), 198-218.

Ellen MacArthur Foundation, 2013. Towards the circular economy, Economic and Business Rationale for an Accelerated Transition, 1. Ellen MacArthur Foundation, London.

Flanagan, C., 2003. Developmental Roots of Political Engagement. Political Science \& Politics 36 (2), 257-261. doi:10.1017/S104909650300218X.

Finnish Ministry of Education and Culture, 2020. Finnish Education System. https: //minedu.fi/en/education-system (accessed on 14.12.2020).

Francis, J.E., Davis, T., 2015. Adolescents' sustainability concerns and reasons for not consuming sustainably. Int. J. Consum. Stud. 39, 43-50.

Geissdoerfer, M., Savaget, P., Bocken, N., Hultink, E., 2017. The Circular Economy - A new sustainability paradigm? J. Clean. Prod. 143, 757-768. doi:10.1016/j.jclepro. 2016.12.048.

Giovannini, E., Hall, J., d'Ercole,, M.M., 2007. Measuring Well-Being And Societal Progress, Conference Beyond GDP - Measuring progress, true wealth, and the well-being of nations. European Parliament, Brussels. 19-20 November 2007 www.beyond-gdp.eu

Gregson, N., Crang, M., Fuller, S., Holmes, H., 2015. Interrogating the circular economy: the moral economy of resource recovery in the EU. Econ. Soc. 44 (2), 1-26. doi:10.1080/03085147.2015.1013353.

Gusstrand Edbring, E., Lehner, M., Mont, O., 2016. Exploring consumer attitudes to alternative models of consumption: motivations and barriers. J. Clean. Prod. 123, 5-15. doi:10.1016/j.jclepro.2015.10.107.

Hill, J.A., 2011. Endangered childhoods: how consumerism is impacting child and youth identity. Media Cult. Soc. 33, 347-363.

Hobson, K., 2016. Closing the loop or squaring the circle? Locating generative spaces for the circular economy. Prog. Hum. Geogr. 40 (I), 88-104. doi:10.1177| 0309132514566342.

Johansson, N., Henriksson, M., 2020. Circular economy running in circles? A discourse analysis of shifts in ideas of circularity in Swedish environmental policy. Sustain. Prod. Consum. 23, 148-156. doi:10.1016/j.spc.2020.05.005.

Keniger, L.E., Gaston, K.J., Irvine, K.N., Fuller, R.A., 2013. What are the benefits of interacting with nature? Int. J. Environ. Res. Public Health 10, 913-935. doi:10. 3390/ijerph10030913.

Kirchherr, J., Reike, D., Hekkert, M., 2017. Conceptualizing the circular economy: An analysis of 114 definitions. Resour. Conserv. Recycl. 127, 221-232. doi:10.1016/j. resconrec.2017.09.005.

Kirchherr, J., Piscicelli, L., Bour, R., Kostense-Smit, E., Muller, J., HuibrechtseTruijens, A., Hekkert, M., 2018. Barriers to the circular economy: evidence from the European Union (EU). Ecol. Econ. 150, 264-272. doi:10.1016/j.ecolecon.2018. 04.028.

Korhonen, J., Honkasalo, A., Seppälä, J., 2018. Circular Economy: The Concept and its Limitations. Ecol. Econ. 143, 37-46. doi:10.1016/j.ecolecon.2017.06.041.

Krippendorff, K., 2004. Content Analysis: An Introduction to Its Methodology, 2nd Edition. Sage: Thousand Oaks, CA.
Krettenauer, T., 2017. Pro-Environmental Behavior and Adolescent Moral Development. J. Res. Adolesc. 27 (3), 581-593. doi:10.1111/jora.12300.

Lazarevic, D., Valve, H., 2017. Narrating expectations for the circular economy: Towards a common and contested European transition. Energy Res. Soc. Sci. 31, 60-69. doi:10.1016/j.erss.2017.05.006.

Maitre-Ekern, E., Dalhammer, C., 2019. Towards a hierarchy of consumption behavior in the circular economy. MJECL 26 (3), 394-420. doi:10.1177/ $1023263 X 19840943$

Martins, N.O., 2016. Ecosystems, strong sustainability and the classical circular economy. Ecol. Econ. 129, 29-32. doi:10.1016/j.ecolecon.2016.06.003.

Max-Neef, M., 1991. Human scale development: conception, application and further reflections. The Apex Press, New York.

Mayring, P., 2004, eds.. In: Flick, U., von Kardoff, E., Steinke, I. (Eds.). A Companion to Qualitative Research, Sage, London, pp. 266-269.

Mhatre, P., Panchal, R., Singh, A., Bibyan, S., 2020. A systematic literature review on the circular economy initiatives in the European Union. Sustain. Prod. and Consum. 26, 187-202. doi:10.1016/j.spc.2020.09.008.

Michaelis, L., Lorek, S., 2004. Consumption and the environment in Europe - trends and futures. Danish Environmental Protection Agency Environmental Project No. 904.

Millar, N., McLaughlin, E., Börger, T., 2019. The Circular Economy: Swings and Roundabouts? Ecol. Econ. 158, 11-19. doi:10.1016/j.ecolecon.2018.12.012.

Murray, A., Skene, K., Haynes, K., 2017. The Circular Economy: An Interdisciplinary Exploration of the Concept and Application in a Global Context. J. Bus. Ethics 140 (3), 369-380. doi:10.1007/s10551-015-2693-2.

Nainggolan, D., Pedersen, A., Smed, S., Zemo, K., Hasler, B., Termansen, M., 2019. Consumers in a Circular Economy: Economic Analysis of Household Waste Sorting Behaviour. Ecol. Econ. 166, 106402. doi:10.1016/j.ecolecon.2019.106402.

Olsson, D., Gericke, N., 2016. The adolescent dip in students' sustainability consciousness: Implications for education for sustainable development. J. Environ. Educ. 47, 35-51. doi:10.1080/00958964.2015.1075464.

Reike, D., Vermeulen, W.J.V., Witjes, S., 2018. The circular economy: New or Refurbished as CE 3.0? - Exploring Controversies in the Conceptualization of the Circular Economy through a Focus on History and Resource Value Retention Options. Resour. Conserv. Recycl. 135, 246-264. doi:10.1016/j.resconrec.2017.08.027.

Ritzer, G., Dean, P., Jurgenson, N., 2012. The Coming of Age of the Prosumer. Am. Behav. Sci. 56 (4), 379-398. doi:10.1177/0002764211429368.

Seyfang, G., 2004. Consuming Values and Contested Cultures: A Critical Analysis of the UK Strategy for Sustainable Consumption and Production. Rev. Soc. Econ. 62 (3), 323-338. doi:10.1080/0034676042000253936.

Sitra, 2019. Circular Economy Teaching for All Level of Education. https:// www.sitra.fi/en/projects/circular-economy-teaching-levels-education/ (accessed on 14.12.2020).

Stern, P.C., 2000. New Environmental Theories: Toward a Coherent Theory of Environmentally Significant Behavior. J. Soc. Issues 56, 407-424. doi:10.1111/ 0022-4537.00175.

Suarez-Eiroa, B., Fernandez, E., Mendez-Martinez, G., Soto-Onate, D., 2019. Operational principles of circular economy for sustainable development: Linking theory and practice. J. Clean. Prod. 214, 952-961. doi:10.1016/j.jclepro.2018.12.271.

UNEP, 2013. In: Reuter, M.A., Hudson, C., van Schaik, A., Heiskanen, K., Meskers, C., Hagelüken, C. (Eds.), Metal Recycling: Opportunities, Limits, Infrastructure. A Report of the Working Group on the Global Metal Flows to the International Resource Panel.

Vergara, S.E., Damgaard, A., Gomez, D., 2016. The Efficiency of Informality: Quantifying Greenhouse Gas Reductions from Informal Recycling in Bogotá, Colombia. J. Ind. Ecol. 20 (1), 107-119. doi:10.1111/jiec.12257.

Vicente-Molina, M.A., Fernández-Sáinz, A., Izagirre-Olaizola, J., 2013. Environmental knowledge and other variables affecting pro-environmental behavior: comparison of university students from emerging and advanced countries. J. Clean. Prod. 61, 130-138. doi:10.1016/j.jclepro.2013.05.015.

Wray-Lake, L., Syvertsen, A.K., Flanagan, C.A., 2016. Developmental change in social responsibility during adolescence: An ecological perspective. Dev. Psychol. 52 (1), 130-142. doi:10.1037/dev0000067.

Wray-Lake, L., Flanagan, C.A., Osgood, D.W., 2010. Examining Trends in Adolescent Environmental Attitudes, Beliefs, and Behaviors Across Three Decades. Environ. Behav 42 (1), 61-85. doi:10.1177/0013916509335163.

Zink, T., Geyer, R., 2017. Circular Economy Rebound. J. Ind. Ecol. 21 (3), 593-602. doi: $10.1111 /$ jiec. 12545 .

Zhong, S., Pearce, J.M., 2018. Tightening the loop on the circular economy: Coupled distributed recycling and manufacturing with recyclebot and RepRap 3-D printing. Resour. Conserv. Recycl. 128, 48-58. doi:10.1016/j.resconrec.2017.09.023. 